\title{
Medicolegal Perspective on Physician-Induced Demand Issue
}

\author{
Wulandari Berliani Putri ${ }^{\mathrm{a}, 1, *}$, Vita Widyasari ${ }^{\mathrm{b}, 2}$, Juliet Musabula ${ }^{\mathrm{c}, 3}$, Muhammad Jihadul Hayat ${ }^{\mathrm{d}, 4}$ \\ ${ }^{a}$ Puskesmas Ngemplak I, Public Health Office Sleman, Yogyakarta, Indonesia \\ ${ }^{\mathrm{b}}$ Faculty of Medicine, Universitas Islam Indonesia, Yogyakarta, Indonesia \\ ${ }^{c}$ Zambia Police Clinics and Hospital, Zambia, South Afrika \\ ${ }^{\mathrm{d}}$ State Islamic University Sunan Kalijaga, Yogyakarta, Indonesia \\ ${ }^{1}$ wulandari.berliani@gmail.com*,2 vita.widyasari@uii.ac.id,3jmusabula@hotmail.com, ${ }^{4}$ mjhayat27@gmail.com \\ * corresponding author
}

\section{ARTICLE INFO}

Article history

Received: January 3, 2021

Revised: July 21,2021

Accepted: July 24, 2021

Keywords

Physician-Induced Demand

Medical Law

Legal Protection of Patient

\section{ABSTRACT}

Physician-Induced Demand has long been a topic in the field of health science. However, compared to medical error or malpractice, PID receives less attention. The term PID itself is not recognized in Indonesian health regulations, but does it mean that the law permits it? This question is essential because the medical law insists that doctors perform medical efforts following professional standards and standard operating procedures. Physician-Induced Demand disguises an action that may manipulate and harm the patient's best interest. This study aims to shed light on the extent to which the medical law protects patients' rights from Physician-Induced Demand conduct. This study employs a juridical and normative approach. Primary resources were collected by investigating health regulations, while secondary resources were obtained from electronic databases. The result of this study shows that PID is a medical action against the will of law. Medical law requires that medical treatment be based on sound principles, such as following high-quality standards, honesty, fairness, humanity, nondiscrimination, efficiency, and effectiveness. Physician-Induced Demand, which tends to the interests of a physician, is opposed to those legal principles. Therefore, this study argues that Physician-Induced Demand violates the principles of medical law. It should be avoided under any circumstances.

This is an open access article under the CC-BY 4.0 license.

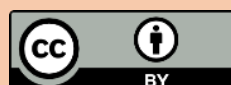

\section{Introduction}

Healthcare expenditure has increased dramatically in the past decades around the world. Indonesia (previously known as the lowest GDP amongst Asian countries) has increased the budget allocation for health from 2.5\% to 5\% of GDP (Stanton et al., 2021). Meanwhile, in the developed country like Australia that has been used Medicare as National health insurance, health spending per capita increased faster than the rest of the economy, from $\$ 4,276$ per person in 2001-02 to $\$ 6,230$ in 201112 (Montazeri et al., 2021). The high demand in healthcare led to accusations of some stakeholders such as the pharmaceuticals industry and physicians. Doctors or Physician-Induced Demand (PID) have been seen to drive the demand in health care (Johnson, 2014). Do they? Health care is a large 
and complex system-many players and factors involved, such as stakeholders, diseases, and government policy and law (Ianole et al., 2014).

The accusation of PID as the leading cause of the increasing demand in healthcare may not seem to acknowledge the existence of legal protection for both patients and doctors. Years ago, doctors were indeed claimed as "God's arm," they are highly respected, and whatever they said or advice, the patients will follow it as they put their trust in doctors (Murdi \& Supanto, 2019). However, in this digital era where information and data are easy to obtain, patients are getting critical and anxious about malpractice, unnecessary examination, and doctors' negligence. Similarly, doctors are aware of medical law and ethics as they know that their patients can sue them easily(Syukriani et al., 2018). The relationship between doctors and patients is sacred, based on trust with a noble purpose. Nevertheless, the gap in information between doctors and patients in a therapeutic transaction may lead to PID (Johnson, 2014). Therefore, to avoid any missed ethical behavior, malpractice, and PID, medical law and medical ethics play a vital role (Syukriani et al., 2018). The study regarding how medical law alludes to the PID is hardly founded. The study regarding how medical law alludes to the PID is hardly founded.

PID its self has long been a topic in the field of health science. Compared to medical error or medical malpractice, PID receives little attention. Therefore, it is not easy to define the extent meaning of PID behavior, but according to Harris, PID occurs when "a physician influences a patient's demand for care against the physician's interpretation of the best interest of the patient"(Harris, 2017). For that matter, studies on PID have been carried out by some scholars are among the scholars who put attention on PID (Celma et al., 2018).

The scholars mentioned above primarily research the relation between PID and the cost of health and the increasing demand for health care. Some of their studies heed economic variables as the main objects of research. For instance, Delattre discusses the relation between fixed costs and doctorinduced demand (Delattre \& Dormont, 2003). Using a panel study approach - to the works of literature regarding the behaviors of French doctors - his research shows that some doctors in Quebec are strategically increasing the number of lucrative procedures to maintain their income (Delattre \& Dormont, 2003). This means that health service procedures based on PID become a channel for Quebec doctors to maintain their economic profit. However, this also depends on the level of physician availability in the country. It also depends on how a country's policy on the fixed cost for medical treatment (Delattre \& Dormont, 2003).

It appears that Delattre's research arguably continues what Wilensky studied about the significance of PID related to the demand for medical care. Previously, Wilensky, in his research, revealed that the results of previous researchers, which stated that there was a positive correlation between the relative number of doctors in an area and the cost of health services, as well as the number of surgeries performed, were not supported by empirical data (Wilensky \& Rossiter, 1983). From these studies, it seems that the study of PID tends to be associated with the increasing quality of health services. It is commonly studied from the perspective of health economics (Johnson, 2014). In a specific country, for instance, Indonesia, where the population of physicians remains in a small ratio compared to the national population, the relationship between patients and doctors seems likely a paternalistic relationship. This paternalism refers to the form of the relationship between father and son (Fraser et al., 2020), which paternalism assumes the doctor is beneficent and focuses on the obligation to the patient (Beisecker \& Beisecker, 1993). This means that one party holds a weaker position within the physician-patient interaction and is quickly being aggrieved (Hou, 2018)

Previous studies seem commonly explore the likelihood of PID to have occurred with the high demand in healthcare. Those studies have not analyzed the legal points of PID. At the same time, in many countries, medical care and medical law have been part of each other. Any medical error can be prosecuted before a penal court and in civil court according to the motive of the aggrieved party. This is because health per se is a part of Human Rights, guaranteed in article 25 of the Universal Declaration of Human Rights. Later on, the right of health has been integrated within The Constitution of Republic Indonesia 1945 and consequently implemented by laws in Indonesia (Syukriani et al., 2018). Some rights cannot be violated and obligations that must be obeyed in the patient-doctor relationship. There are also medical ethics that physicians cannot ignore. At that border, PID as part of the doctor's "deviant" behavior can be considered as a practice that potentially violates patient right in any 
circumstances of medical treatments. It is like a negation of law objectives: utility, certainty, and justice (Mylius, 2018). Therefore, based on those arguments above, this paper will discuss PID from the perspective of Medical Law. This PID is intriguing to be elaborated on since the subject receives little attention, particularly in the frame of legal approach. Furthermore, to what extent the law in protecting the rights of patients from PID behavior is the question of this paper.

\section{Research Method}

Data were collected from electronic databases, MEDLINE Ovid and EBSCO. Keywords are entered into the database's search box to attain the related papers. The combinations of terms are namely: supply-demand determinants, health insurance, physician-induced demand, asymmetry information, healthcare expenditure, medical law, medical practice, informed consent, and medical error. During the initial search, neither language nor publication year was restricted (Tan et al., 2021). Other journals were discovered using the reference lists of the journals obtained as well as Google scholar searches. The full-text references were examined, as well as relevant cited publications that were relevant to the study's objective. The authors extracted relevant data from all of the included studies (Hou, 2018).

\section{Results and Discussion}

\subsection{Defining Physician-Induced Demand (PID)}

From a legal perspective, an action that is consciously conducted, deliberately, and willingly resulting from the law is called legal action. Thus, the basis of the legal relationship between doctors and patients in providing health service assistance is articles 1330 and 1354 Civil Code. 9 Further, there are rules, etiquette, and norm in medical practice that play as vital barriers for medical action, such as physician-induced demand theory. Physicians are the key players in health care services. Their role as health care providers and decision-makers is often blamed for the high cost. PID is attributed to the ability of doctors to influence patient demand according to doctor self-interest (Montazeri et al., 2021).

This hypothesis is derived from the asymmetry of knowledge between agent (doctor) and consumer (patient). PID has been studied for years, yet its existence is difficult to prove.13 Most studies do not provide a detailed analysis of whether patient treatment is based on PID or patient preference. The confounding factors (uncertainty of clinical outcomes, expectations of family or caregivers, and cultural backgrounds) were not explicitly analyzed and were the weaknesses of the PID study (Maeda et al., 2016).

Physician behavior does respond to income fluctuation. Undoubtedly some physicians violate their role as agents. For example, in New York, the USA, coronary stenting abuse cases by a cardiologist, where the doctor performed unnecessary coronary stenting. However, despite these cases, we can still ask, 'Do all physicians violate their role as agents?', 'How many of them are likely to misuse their power as agents?'. Doctor acts are bound by a sacred oath, where medical ethics act to constrain doctor behavior. A modern version of the Hippocratic Oath pledge "I will apply, for the benefit of the sick, all measures [that] are required, avoiding those twin traps of overtreatment and therapeutic nihilism" describes the physicians as well-respected professionals. They cannot be free to merely behave and conduct for their interest, overriding patient need (Dossabhoy et al., 2018).

In Australia, a code of conduct is also established by the Medical Board of Australia to limit and oversee opportunistic behavior by doctors to drive a doctor-driven demand (Balasubramanian et al., 2021). The theory of PID predicts an overtreatment by a physician. However, it is inconsistent with Chen and Vargas-Bustamante's (2013) study that physician orders are often ignored by patients due to a lack of trust, specifically when the patient suspects a doctor's financial motive (Chen \& VargasBustamante, 2013). Additionally, in Europe, physician incomes have not increased remarkably in the past decades. Hence, if doctors are the people responsible for the increasing demand in health care, it would logically follow that their income would also have increased.

However, PID can be claimed as a condition where physicians are responsible for the demand of 'unnecessary' supporting examinations such as advanced medical technology, laboratories, and other 
additional examinations. This situation may arise from the development of defensive medicine, a distortion of medical care triggered by malpractice suit nowadays (Syukriani et al., 2018). Physicians try to avoid and defend themselves from the risk of indictment by playing safe and being overly careful by undertaking excessive diagnostic tests to ensure that they will not be charged from medico-legal suits. To protect both doctors and patients, the Indonesian government released a Minister of Health Regulations number 11 the year 2017 regarding patient safety that aims to increase the quality of services of health care facilities through risk management in all aspects of services provided by health care facilities.20 Occasionally, regulation or law can also stimulate physicians to behave and act more carefully than before, even exaggerated to advise unnecessary diagnostic tests before conducting the therapeutic transaction. A study from Haripriya (2014) found that most doctors (79.2\%) are aware of the code of medical ethics and have sufficient knowledge of the medico-legal aspect.

\subsection{Looking at the Cause of PID: Asymmetry Information}

Many studies argue that PID mainly occurred due to asymmetry information. It is the situation where physicians can affect the demand because they have superior medical knowledge to their patients (Johnson, 2014). Patients may have less information, but the potential for consumer response confines what even the most self-interested doctor can get away with. In addition, how credible the information asymmetry model is to prove that the demand in health care driven by PID. (Sekimoto \& Ii, 2015) There are numerous limitations of this asymmetry information model to be the cause of PID, firstly, patients are well-informed in many cases, such as diagnostic screening of breast cancer, vaccination, medical check-ups, and chronic diseases, which require frequent monitoring and evaluation to prevent complications. These well-informed conditions represent half of total GP (General Practitioner) visits. Secondly, in many cases, patients also seek second opinions regarding their health problems, particularly for new health issues. Thirdly, the physician's common goal is to achieve the patient's health outcome, as it is a vital variable in the physician's utility function. Therefore, patient satisfaction on the quality of service may turn to demand.

The problem of information is in the asymmetry of information and the uncertainty faced by both the doctor and patient. An appropriate anamnesis and physical examination may help the doctor establish a diagnosis. However, many cases need advanced procedures to do this. For instance, when the doctor is $80 \%$ certain that it is a stroke, s/he must perform a Head CT-Scan to determine whether it is a hemorrhagic stroke or ischemic stroke. According to evidence-based practice, the Head CTScan is the gold standard of stroke diagnosis, and this procedure has been a standard protocol (Bai et al., 2021). This uncertainty area faced by doctors and patients contributes to the increased use of medical technology.4 In this case, a doctor cannot be blamed for inducing demand; instead, a doctor should perform the diagnostic test to save the patient's life, although there must be an inform-consent first before conducting the CT-Scan test.

Further, it is essential to remember that this asymmetry of information is protected and bridged by informed consent from the legal aspect (Syukriani et al., 2018). It is clear that all the doctor's suggestions do not have to be approved by the patient. Patients have the right either to accept or to decline doctor's preferences or advice. Informed consent is the backbone of medical practice ethics. Almost all medical action requires informed consent. There is no medical action without informed consent for sure, but if so, it would be categorized as medical malpractice. In Indonesia, medical practice regulation and informed-consent matters are stated explicitly in Article 7 paragraph (3) Minister of Health Regulation No. 290/MENKES/PER/III/2008; Article 5 Indonesian Medical Association decision letter No.111/PB/A.4/02/2013; and Indonesian Law Number 29 of 2004 concerning Medical Practice Article 45 declared that "Any medical or dental action that a doctor or dentist will perform on a patient must be approved by the patient." In more detail, the following article in the same enactment explained that the approval should be given after having a clear explanation comprising diagnosis, procedures, purposes, alternative medication and its risks, the risks, and complications that potentially occur, and the prognosis of the treatment to be given. In the case where doctor requires conducting an extension of medical action that only discover when performing surgery is also included in the informed-consent explanation protected in Indonesian Law Number 29 of 2004.25. Hence, this may explain that asymmetry information should not be blamed as the salient reason PID occurred (Mohammadshahi et al., 2019).

Informed consent could be given orally and written. However, any high-risk action of medical or dental must be given with a written consent signed by the person entitled to give consent. According 
to Indonesian Law Number 29 of 2004, the patient's legal implication of refusing medical action is that the patient has given up his legal rights to the doctor in undesirable things, which means the doctor is free from all legal consequences that arise after the refusal (Syafruddin et al., 2020). Similarly, article 45 lex number 44 the year 2009 about Hospital administrations stated that Hospital is not legally responsible if the patient and/or family refuse or stop the treatment, resulting in the patient's death after a comprehensive medical explanation.

Several works of literature clarified that in Indonesia, medical malpractice could be prosecuted under Article 351 of the Criminal Code, Article 1366 of the Civil Code, or Article 1365 of the Civil Code.9,27 However, it should be distinguished between crime act, medical malpractice, and medical negligence. It would be biased to sentence a clinician who tried to save a life, yet she/he was charged with criminal law. Some laws or organizations regulate and supervise medical practice in Indonesia, such as Health Workforce Disciplinary Council, Medical Ethics Honorary Council, and Indonesian Medical Council, that could apply administrative sanctions such as withdrawing the medical practice license. These are established organizations that regulate and apply any kinds of sanctions for physicians ideally (Murdi \& Supanto, 2019), physician who is suspected crossing the ethical code or even malpractice, should be brought to the medical disciplinary and ethics honorary council to be investigated first whether he is wrong or not, if he proven violates the standard medical procedure then the case would continue to the court. Although many boards supervised physicians, it does not mean that physician is immune to the criminal law.

From a different perspective, almost all countries facing difficulties concerning informed consent. Informed consent is a complex matter. It is not as simple as had been accentuated in many regulations or laws. Often, a physician's diagnosis could be suddenly changed as the disease's pathway is not as same as mathematical. For instance, in the case of obstetric, emboli or even sudden fetal distress could rapidly occur anytime. Patients have to understand that any delivery process is a risky procedure although in the early condition were all good. Another situation is that patients from low socioeconomic backgrounds mostly do not understand what their rights and obligations are. Commonly they just follow and agree to what the doctors said. In this situation, would the doctor do misconduct to use their power in an asymmetry of information to get more incentive or increasing the demand? When the patient is protected by health insurance, this probably will happen triggered by the doctor's moral hazard (Sekimoto \& Ii, 2015).

The physician's obligation is to give a clear and detailed explanation to patients as there is a gap of knowledge. However, providing detailed and long information has an impact on the patient's confusion about too much information he receives. A short, simple, and clear explanation are what the patient needs. Further, this could also be a dilemma, when there is a risk of surgery that occurred, and patient feels that he was not explained by the doctor about the specific matter, then the patient will feel cheated. While providing a detailed medical explanation in a short time is also impossible, it will take a longer time, whereas the patient needs help as soon as possible. Doctors must be wise in providing simple and thorough explanations to patients. Based on ethical and legal positions is clear, doctors must not keep any information simply because they disagree with the patient's decision is given that information. The doctor's duty is to reassure the patient to get thorough medical information, so when the patient signs the informed consent, he is in a conscious state and knowing all the risks he would possibly receive. The thing should be highlighted here is successful communication, trust to each other, and doctor's empathy to the patient.

\subsection{Health Insurance and Moral Hazard}

The total expenditure on health in Indonesia was only $2.9 \%$ of GDP or \$299 per capita in 2014.28. This makes Indonesia remains low amongst Asian countries at that time. However, since 2014, when Indonesia has started implementing the national health insurance policy - under the management of the Social Security Administrator Agency for Health (BPJS) - the health expenditure of Indonesian people begins to rise. The number of patients, either outpatient or inpatient, is dramatically increasing. 29 Currently, the Indonesian government is adding the allocation of budget for health up to $5 \%$ of GDP to support the needs of people in healthcare.

The existence of health care insurance influences the demand-supply interaction.3 Health insurance is closely linked to moral hazard either from consumers (patients) or suppliers (doctors). Both consumers and doctors may utilize or provide more services when these are insured.30,31 The 
aging population plus the high coverage by insurance reinforce this possibility. The moral hazard of consumers toward insurance arises similarly in normal economic behavior, where consumer demand increases in response to a lower price. In insurance cases, consumers who are insured are facing zero price. Consumers desire to gain additional benefits for themselves at the expense of the insurance provider and so may use more services than needed simply because they are not paying (Johnson, 2014). Hence, both moral hazard and the existence of health insurance contribute to the increasing demand for health care.

Considering the cost efficiency, Social Security Administrator Agency for Health (BPJS) implement a tiered referral system. This requires patients to seek a primary healthcare doctor first instead of a directly go-to specialist. The expectation is that the patients' medical problems can be solved comprehensively in primary care, where the cost is lower than in hospitals (Anggraeni et al., 2020). Further, if the doctor decided that the patient should meet higher health services (hospital), the doctor would refer the patient to the hospital.

The problem is that this tiered referral system may create an ethical issue, where either patients or doctors can commit fraud. For instance, a patient forcing a primary care doctor to make a referral so that the patient can meet a specialist or to request an advanced examination in a hospital, or vice versa. This example case is an ethical violation by both the patient and doctor, although no medical law has been violated. Moral hazard is challenging to be proven, yet it can trigger the high demand in healthcare eventually and no criminal or medical law has been disrupted.

\subsection{Legal Relationship of Doctor-Patient}

In everyday life situations, when people suffer from disease or have health problems, they see the doctors get medical advice or medical treatments. It is a common situation that there is no pre-written agreement between patient and doctor about the medical treatment provided as if there has no bond between them. This goes since the patient believes that the doctor is the expert and part of the solution. The relationship between them seems to occur merely based on trust. The patient trusts the doctor, and the doctor implies the existence of trust (Beisecker \& Beisecker, 1993). In this level, doctor and patient agree on a paternalistic relationship. This relationship seems to be one party is more superior to the other. The doctor is considered to know more about the patient's illness than the patient himself. This type of relationship is certainly an unbalanced relationship which puts a higher risk on the weaker parties. To prevent an unwanted future, the law protects the parties. When the medical treatment process occurs, there is an indirect agreement between the doctor and patient, called a transaction between the two in terms of health. This transaction is called a therapeutic transaction.

Transaction means an agreement that brings to a reciprocal relationship between two parties regarding a matter. In this case, the transaction is an agreement between a doctor and a patient, which authorizes the doctor to perform medical actions to cure the patient illness based on the doctor's expertise and skills. Departing from this transaction, rights and obligations were born between the two parties (Cheluvappa \& Selvendran, 2020). Therefore, the relationship between doctors and patients is a relationship between legal subject to legal subject. both the doctor and the patient are is legal subjects, each of whom voluntarily and without coercion binds themselves into a contract referred to as a therapeutic contract (Cheluvappa \& Selvendran, 2020). Based on this contract, all medical actions from doctors toward patients can be accounted as legal actions and implies legal liability (Cheluvappa \& Selvendran, 2020). The type of contract that occurs is an inspannings verbintenis agreement. Inspannings verbintenis is an agreement where the doctor will provide every effort, giving his maximum competence, to cure the patient (Putra, 2001). The point of the agreement is not on the result (resultaats verbintenis) but the maximum effort. The maximum effort means that the doctor should perform the medical action under the correct professional standard and the correct standard operating procedure (SOP) according to medical science (Debono et al., 2020).

In addition to the legal relationship caused by therapeutic transactions (ius contracto), a legal relationship between doctor and patient can also be formed based on zaakwaarneming, which means a voluntary act of taking care of someone's interest with/without the consent of that person. In Medical Law, zaakwaarneming can be found in a medical emergency case. According to zaakwaarneming principle, medical emergency action can be taken even without the patient's consent. A good example is the case of a bad accident whereby an unconscious patient must be treated immediately without waiting for his/her family. Even slightly different than zaakwaarneming, the action of taking care of 
someone's interest in this situation has been justified by the law (ius delicto) according to article 1354 Indonesian Civil Code (Burgerlijke Wetboek).

"If a person voluntarily, without being assigned, represents another person's interest, with or without that person's consent, then he is secretly binding himself to continue and settle the matter until the person he represents can do the business himself'.

General provision regarding the form of agreement has been regulated in the Civil Code (Burgerlijke Weboek). According to Article 1313 of the Civil Code, an agreement is an act in which one or more persons bind themselves to one or more other people's interests. Based on the explanation above, it is safe to say that the legal relationship between doctor and patient is a civil-contract relationship because it is based on civil agreement. Hence this relationship emerges from three reasons: (1) therapeutic contract in the form of inspanning verbintenis, (2) voluntary action by the doctor in the form of zaakwaarneming, and (3) mandate of the law in the case of a medical emergency.

\subsection{Protection of Patient Rights}

The relationship between doctor and patient can no longer be considered as vertical paternalistic, but an equal relationship. This relationship is based on the principle of a harmonious agreement (Worthington et al., 2014). This is in accordance with the principle of patient autonomy, where every individual has freedom and equal rights to health services and care. The principle of patient autonomy is based on the International Convention on the Universal Declaration of Human Rights article 25 paragraph (1), and The Constitution of Republic Indonesia 1945 article $28 \mathrm{H}$ paragraph (1) jo article 34 paragraph (3) (Haeranah et al., 2020).

"Everyone has the right to a standard of living adequate for the health and well-being of himself and of his family, including food, clothing, housing and medical care and necessary social services, and the right to security in the event of unemployment, sickness, disability, widowhood, old age or other lack of livelihood in circumstances beyond his control" (Petrini, 2016).

Every person is entitled to live prosperous physically and spiritually, to have a place to reside, and to acquire a good and healthy living environment as well as be entitled to obtain health care. The state shall be responsible for the provision of decent health care facilities and public service facilities (Huda et al., 2021)

Based on patient autonomy, the rights of patients as legal subjects have been protected by the law. The right of the patient will be summarized in the table 1 .

Table 1. Patient Rights in Health Laws

\begin{tabular}{|c|c|c|c|}
\hline Act & Article & Subject & Right \\
\hline Act No. & Article 52 & Patient & get a complete explanation of the medical procedure; \\
\hline \multirow{4}{*}{$\begin{array}{l}29 \text { Year } 2004 \\
\text { about Medical } \\
\text { Practice }\end{array}$} & & & seek the opinion of another doctor or dentist; \\
\hline & & & get services according to medical needs; \\
\hline & & & refuse medical treatment; and \\
\hline & & & get the contents of the medical record. \\
\hline \multirow{2}{*}{$\begin{array}{l}\text { Act No. } 36 \text { Year } \\
2009 \text { about } \\
\text { Health }\end{array}$} & Article 4 & Every person & right to health \\
\hline & $\begin{array}{l}\text { Article } \\
\text { paragraph (1) }\end{array}$ & Every person & $\begin{array}{l}\text { have the same rights in obtaining access to resources in } \\
\text { the health sector, have the right to obtain safe, quality, and } \\
\text { affordable health services, and have the right to be }\end{array}$ \\
\hline
\end{tabular}


independent and responsible for determining the health services needed for themselves.

\begin{tabular}{llll}
\hline $\begin{array}{l}\text { Article } \\
\text { paragraph (2) }\end{array}$ & 5 & Every person & $\begin{array}{l}\text { have the right to obtain safe, quality, and affordable health } \\
\text { services. }\end{array}$ \\
\hline $\begin{array}{l}\text { Article } \\
\text { paragraph (3) }\end{array}$ & 5 & Every person & $\begin{array}{l}\text { have the right to independently and responsibly determine } \\
\text { the health services needed for themselves }\end{array}$ \\
\hline Article 6 & Every person & $\begin{array}{l}\text { entitled to a healthy environment for the achievement of } \\
\text { health status }\end{array}$
\end{tabular}

\begin{tabular}{lll}
\hline Article 7 & Every person & $\begin{array}{l}\text { have the right to get information and education about } \\
\text { balanced and responsible health }\end{array}$
\end{tabular}

Article 8 Every person has the right to obtain information about his/her health data including actions and treatments that have been or will be received from health workers.

\begin{tabular}{lll}
\hline $\begin{array}{l}\text { Article } \\
\text { paragraph (1) }\end{array}$ & $\begin{array}{l}\text { Every person } \\
\text { has the right to accept or reject part or all of the relief } \\
\text { measures that will be given to him after receiving and } \\
\text { fully understanding the information regarding the action }\end{array}$ \\
\hline $\begin{array}{l}\text { Article } \\
\text { paragraph (2) }\end{array}$ & $\begin{array}{l}\text { The right to accept or reject as referred to in paragraph (1) } \\
\text { does not apply to: }\end{array}$
\end{tabular}

patient whose disease can quickly spread to the wider community;

the state of an unconscious person; or,

severe mental disorder.

\begin{tabular}{llll}
\hline $\begin{array}{l}\text { Article } \\
\text { paragraph (1) }\end{array}$ & $\begin{array}{l}\text { Every person } \\
\text { Article } 58 \\
\text { paragraph (1) }\end{array}$ & $\begin{array}{l}\text { has the right to the confidentiality of his health condition } \\
\text { that has been disclosed to the health service provider }\end{array}$ \\
& $\begin{array}{l}\text { has the right to claim compensation for a person, health } \\
\text { worker, and/or health provider who causes a loss due to } \\
\text { an error or negligence in the health service he/she } \\
\text { receives. }\end{array}$
\end{tabular}

\begin{tabular}{ll}
\hline Article 58 & The claim for compensation as referred to in paragraph (1) \\
paragraph (2) & does not apply to health workers who commit
\end{tabular}

life-saving action or prevention of a person's disability in an emergency

\begin{tabular}{|c|c|c|c|}
\hline Act No. 44 Year & Article 32 & Every person & $\begin{array}{l}\text { obtain information about the rules and regulations that } \\
\text { apply in the hospital; }\end{array}$ \\
\hline \multicolumn{4}{|l|}{2009 about } \\
\hline Hospital & & & $\begin{array}{l}\text { obtain information about the patient's rights and } \\
\text { obligations; }\end{array}$ \\
\hline & & & $\begin{array}{l}\text { obtain services that are humane, fair, honest, and without } \\
\text { discrimination; }\end{array}$ \\
\hline & & & $\begin{array}{l}\text { obtain quality health services in accordance with } \\
\text { professional standards and standard operating procedures; }\end{array}$ \\
\hline
\end{tabular}


obtain effective and efficient services so that patients avoid physical and material losses;

file a complaint on the quality of service obtained;

choose a doctor and treatment class based on his/her wishes and the applicable regulations in the Hospital;

ask for a consultation about the illness he is suffering from to another doctor who has a Practice License (SIP) both inside and outside the Hospital;

obtain privacy and confidentiality of the illness, including medical data;

obtain information which includes diagnosis and procedures for medical action, the purpose of medical action, alternative actions, risks and complications that may occur, and the prognosis of the actions taken as well as the estimated cost of treatment;

approve or refuse the action to be taken by the health worker against the disease he is suffering from;

accompanied by his family in critical condition;

perform worship according to his religion or belief as long as it does not disturb other patients;

obtain security and safety for himself while in hospital for treatment;

submit proposals, suggestions, improvements to the Hospital's treatment of him;

refuse spiritual guidance services that are not in accordance with their religion and beliefs;

sue and/or sue the Hospital if the Hospital is suspected of providing services that are not based on standards, both civil and criminal; and

complain about hospital services that are not based on service standards through print and electronic media in accordance with the provisions of the legislation.

Table 1 shows, the PID is not mentioned literally. This does not mean that PID does not constitute in those articles. Substantively PID can be categorized as an abortive work that is not qualified good intention by doctors. This is accommodated in Article 5 paragraph (2) of Act No. 36 of 2009 about Health. PID as a medical action that is not oriented to the best interests of the patient is undoubtedly contrary to the article, which requires quality and affordable services. Quality means good service according to the best interests of the patient, either morally, physically, or economically. PID that is not oriented to the best interests of the patient also violates the rules in Article 32 letters c, d, e of Act No. 44 of 2009 about Hospitals.

According to this Article, Hospital (including physicians) must ensure the implementation of patient rights, which is included in the form of services based on humane, fair, honest, and without discrimination; quality following professional standards and standard operating procedures; effective 
and efficient so that patients avoid physical and material losses. PID, as described above, is not under the principles of health services based on professional standards and standard operating procedures. PID is contradicting to the efficient and effective service. PID is also not a medical treatment based on the just and moral sense of humanity. Therefore, if the PID conducted proven to violate the patient's right, doctors and hospitals can be prosecuted according to Article 58 paragraph (1) of Act No. 36 of 2009 about Health jo Article 32 letter q of Act No. 44 of 2009 about Hospitals. In terms of medical law, each country has their own constitution. Indonesia has regulated medical practice in the Indonesian Law of Medical Practice number 292004 which comprises the foundation and purposes of medicine and dentistry practice, the establishment of Indonesian Council of Medicine, physician registration, preparation, determination, and ratification of medical and dentists professional education standards, medical practice, the establishment of the Indonesian Medical Discipline Honorary Council, guidance and supervision of medical practice, and criminal provisions regulation

Article 45 Indonesian Law number 29 of 2004 has accentuated informed-consent, which is believed as one of tools to avoid strong medical paternalistic. Physicians or doctors have to respect patient's autonomy. They should explain all the condition, treatment preference, side effect, risk, complications and prognosis prior any medical act to patient. The informed-consent could be convey through orally and written. Most of the time, written informed-consent is preferably as it is safer and accountable for both stakeholders.

There is no specific medical practice law to prevent PID occurred in Indonesia. This review, stressed the key factor to brake PID through informed-consent which mentioned in article 45. Additionally, in the same medical law, article 49 had actually explained that any healthcare providers have to conduct the quality and cost control. It means that healthcare facilities as well as physicians on their practice have to respect the patients, law, regulations, and the professional code of ethics that oriented to patient's safety and wellbeing. Cost control in a simple definition is a payment given on the principle of appropriateness in accordance with the goods and services that have been used by patient without harming the patient. In public sector there is a standard rate that declared by government's regulation. While in private, although the cost of healthcare services is more expensive, it should not exceed the national standard.

Meanwhile in Zambia, the Health Profession Act Number 24 of 2009 in part VII about Disciplinary Committee has clearly stated a health practitioner commits professional misconduct if the health practitioner, contravenes the provisions of this Act, unlawfully discloses or uses to the health practitioner's advantage any information acquired in the health practitioner's practice, engages in conduct that is dishonest, fraudulent or deceitful, commits an offence under any other law, engages in any conduct that is prejudicial to the health profession or is likely to bring it into disrepute, and breaches the Code of Ethics or encourages another health practitioner to breach or disregard the principles of the Code of Ethics

According to Zambia medical law, PID case could be included in point (c) that is dishonest, fraudulent, or deceitful. Further, Zambia in 2016 has released a guideline for good practice especially how to obtain patient's informed-consent in a very detailed method. Starting from what informedconsent is, what explanation should be convey and how to convey until patient understand, who should receive and sign the consent, etc. (Mayeya et al., 2004) Apparently, this guideline is established due to the cases of many patients there in Zambia do not understand what informed-consent is, what their autonomy or right. (Mayeya et al., 2004) The issues in Zambia, Indonesia, and many other countries in the term of informed-consent is similar.

Most patient agree with what physician's said as they believed that is for the sake of their health. In order to reduce the PID phenomenon, there are five potential solutions. First, establishing a guideline of good clinical practice. Second, establishing a guideline of how to obtain patient's informed-consent. Third, communication skill course is needed for healthcare professional, especially how to deal with various groups of people. Fourth, quality and cost controlling by the government to prevent PID. Fifth is adequate payment system for physicians. These points are urgently needed as it helps physicians to be more aware and developing a better skill and quality. 


\section{Conclusion}

The term Physician-Induced Demand is not mentioned in multi health regulations, but it does not mean that the PID is allowed. PID is a medical intervention that is geared toward the interests of physicians. Substantively, PID refers to an action that can overlap the patient's interest. At the same time, medical law emphasizes that a doctor is required to follow medical steps according to professional standards and standard operating procedures. Furthermore, the medical law also requires that medical treatment be based on sound principles, such as following high-quality standards, honesty, fairness, humanity, nondiscrimination, efficiency, and effectiveness. As a result, PID is a medical procedure that violates medical law and medical ethics. According to regulation and medical law, it is safe to conclude that PID is a medical action against the will of law. Any party who receives such medical treatment has the right to pursue those responsible for the PID.

\section{References}

Anggraeni, R., Marzuki, D. S., Mangilep, A. U., Irwandy, Rizki, F., Basman, M. H., \& Darussalam, F. A. (2020). The evaluation of national health assurance governance program in Makassar City and Gowa District of South Sulawesi Province. Enfermería Clínica, 30, 17-20. https://doi.org/10.1016/j.enfcli.2020.06.006

Bai, X., Zhang, X., Wang, T., Feng, Y., Wang, Y., Lyu, X., Yang, K., Wang, X., Song, H., Ma, Q., Ma, Y., \& Jiao, L. (2021). General anesthesia versus conscious sedation for endovascular therapy in acute ischemic stroke: A systematic review and meta-analysis. Journal of Clinical Neuroscience, 86, 10-17. https://doi.org/10.1016/j.jocn.2021.01.012

Balasubramanian, M., John Spencer, A., Sohn, W., \& Brennan, D. S. (2021). The Practice of Dentistry by Australian- and Overseas-Trained Dentists in Australia: Discriminant Analysis of key Predictors. International Dental Journal. https://doi.org/10.1016/j.identj.2021.01.002

Beisecker, A. E., \& Beisecker, T. D. (1993). Using Metaphors to Characterize Doctor-Patient Relationships: Paternalism Versus Consumerism. Health Communication, 5(1), 41-58. https://doi.org/10.1207/s15327027hc0501_3

Celma, D., Martinez-Garcia, E., \& Raya, J. M. (2018). Socially responsible HR practices and their effects on employees' wellbeing: Empirical evidence from Catalonia, Spain. European Research on Management and Business Economics, 24(2), 82-89. https://doi.org/10.1016/j.iedeen.2017.12.001

Cheluvappa, R., \& Selvendran, S. (2020). Medical negligence - Key cases and application of legislation. Annals of Medicine and Surgery, 57, 205-211. https://doi.org/10.1016/j.amsu.2020.07.017

Chen, J., \& Vargas-Bustamante, A. (2013). Treatment compliance under physician-industry relationship: a framework of health-care coordination in the USA. International Journal for Quality in Health Care, 25(3), 340-347. https://doi.org/10.1093/intqhe/mzt017

Debono, B., Hamel, O., Guillain, A., Durand, A., Rué, M., Sabatier, P., Lonjon, G., \& Dran, G. (2020). Impact of malpractice liability among spine surgeons: A national survey of French private neurosurgeons. Neurochirurgie, 66(4), 219-224. https://doi.org/10.1016/j.neuchi.2020.05.003

Delattre, E., \& Dormont, B. (2003). Fixed fees and physician-induced demand: A panel data study on French physicians. Health Economics, 12(9), 741-754. https://doi.org/10.1002/hec.823

Dossabhoy, S. S., Feng, J., \& Desai, M. S. (2018). The Use and Relevance of the Hippocratic Oath in 2015a Survey of US Medical Schools. Journal of Anesthesia History, 4(2), 139-146. https://doi.org/10.1016/j.janh.2017.09.005

Fraser, S., Fomiatti, R., Moore, D., Seear, K., \& Aitken, C. (2020). Is another relationship possible? Connoisseurship and the doctor-patient relationship for men who consume performance and image$\begin{array}{llllll}\text { enhancing drugs. Social Science \& } & \text { Medicine, } & 246, & \end{array}$ https://doi.org/10.1016/j.socscimed.2019.112720 
Haeranah, Patittingi, F., Muhadar, Muchtar, S., Hasrul, M., Azisa, N., Lahae, K., Latif, B., \& Bakhtiar, H. S. (2020). Health and law: Euthanasia in Indonesian legal perspective. Enfermería Clínica, 30, 492-495. https://doi.org/10.1016/j.enfcli.2019.10.128

Harris, B. (2017). No Title. Economics \& Human Biology, 27, 336-338. https://doi.org/10.1016/j.ehb.2017.09.006

Hou, B. (2018). An Investigation of Physician-Induced Demand in China's Health Care System: Evidence from the Charls. Innovation in Aging, 2(suppl_1), 738-738. https://doi.org/10.1093/geroni/igy023.2724

Huda, N., Nur Heriyanto, D. S., \& Gani Wardhana, A. F. (2021). The urgency of the constitutional preview of law on the ratification of international treaty by the Constitutional Court in Indonesia. Heliyon, 7(9), e07886. https://doi.org/10.1016/j.heliyon.2021.e07886

Ianole, R., Druică, E., \& Cornescu, V. (2014). Health Knowledge and Health Consumption in the Romanian Society. Procedia Economics and Finance, 8, 388-396. https://doi.org/10.1016/S2212-5671(14)00105-1

Johnson, E. M. (2014). Physician-Induced Demand. Encyclopedia of Health Economics, 3, 77-82. https://doi.org/10.1016/B978-0-12-375678-7.00805-1

Maeda, T., Babazono, A., Nishi, T., Yasui, M., \& Harano, Y. (2016). Investigation of the Existence of SupplierInduced Demand in use of Gastrostomy Among Older Adults. Medicine, 95(5), e2519. https://doi.org/10.1097/MD.0000000000002519

Mayeya, J., Chazulwa, R., Mayeya, P. N., Mbewe, E., Magolo, L. M., Kasisi, F., \& Bowa, A. C. (2004). Zambia mental health country profile. International Review of Psychiatry, 16(1-2), 63-72. https://doi.org/10.1080/09540260310001635113

Mohammadshahi, M., Yazdani, S., Olyaeemanesh, A., Akbari Sari, A., Yaseri, M., \& Emamgholipour Sefiddashti, S. (2019). A Scoping Review of Components of Physician-induced Demand for Designing a Conceptual Framework. Journal of Preventive Medicine and Public Health, 52(2), $72-81$. https://doi.org/10.3961/jpmph.18.238

Montazeri, K., Dranitsaris, G., Thomas, J. D., Curran, C., Preston, M. A., Steele, G. S., Kilbridge, K. L., Mantia, C., Ravi, P., McGregor, B. A., Mossanen, M., \& Sonpavde, G. (2021). An economic analysis comparing health care resource use and cost of dose-dense methotrexate, vinblastine, doxorubicin, and cisplatin versus gemcitabine and cisplatin as neoadjuvant therapy for muscle invasive bladder cancer. Urologic Oncology: Seminars and Original Investigations. https://doi.org/10.1016/j.urolonc.2021.04.032

Murdi, P. B., \& Supanto, W. T. N. (2019). The Role of Indonesian Honorary Council of Medical Discipline in Upholding Indonesian Medical Code of Ethics. Proceeding Advances in Social Science, Education and Humanities Research, Atlantis Press, 358. https://dx.doi.org/10.2991/icglow-19.2019.28

Mylius, B. (2018). Earth Jurisprudence. In D. A. Dellasala \& M. I. Goldstein (Eds.), Encyclopedia of the Anthropocene (pp. 271-276). Elsevier. https://doi.org/10.1016/B978-0-12-809665-9.10449-5

Petrini, C. (2016). Organ Allocation Policies 10 Years After UNESCO's Universal Declaration on Bioethics and Human Rights. Transplantation Proceedings, 48(2), 296-298. https://doi.org/10.1016/j.transproceed.2015.10.059

Putra, Sarsintorini. (2001). Inspannings verbintenis dan Resultaats verbintenis dalam Transaksi Terapeutik Kaitannya dengan UU No. 8 Tahun 1999 tentang Perlindungan Konsumen. Jurnal Hukum IUS QUIA IUSTUM, 8(18), 199-211. https://doi.org/10.20885/iustum.vol8.iss18.art14

Sekimoto, M., \& Ii, M. (2015). Supplier-Induced Demand for Chronic Disease Care in Japan: Multilevel Analysis of the Association between Physician Density and Physician-Patient Encounter Frequency. Value in Health Regional Issues, 6, 103-110. https://doi.org/10.1016/j.vhri.2015.03.010

Stanton, R., Best, T., Williams, S., Vandelanotte, C., Irwin, C., Heidke, P., Saito, A., Rebar, A. L., Dwyer, T., \& Khalesi, S. (2021). Associations between health behaviors and mental health in Australian nursing students. Nurse Education in Practice, 53, 103084. https://doi.org/10.1016/j.nepr.2021.103084

Syafruddin, Rohman, A., \& Ilyas, A. (2020). Informed consent: Criminal impact in negligence of medical action. Enfermería Clínica, 30, 258-263. https://doi.org/10.1016/j.enfcli.2020.06.059 
Syukriani, Y. F., Novita, N., \& Sunjaya, D. K. (2018). Development of forensic medicine in post reform Indonesia. Journal of Forensic and Legal Medicine, 58, 56-63. https://doi.org/10.1016/j.jflm.2018.05.001

Tan, S., Hamilton, G., \& Layland, J. (2021). Letter to the Editor Regarding: "Cost-Effectiveness of Cardiovascular Magnetic Resonance in Diagnosing Coronary Artery Disease in the Australian Health Care System”, Heart Lung Circ. 2021;30(3):380-387. Heart, Lung and Circulation, 30(10), e115-e116. https://doi.org/10.1016/j.hlc.2021.04.024

Wilensky, G. R., \& Rossiter, L. F. (1983). The relative importance of physician-induced demand in the demand for medical care. The Milbank Memorial Fund Quarterly. Health and Society, 61(2), 252-277. https://doi.org/10.2307/3349907

Worthington, R. P., Becker, G., \& Hays, R. (2014). Appraising the profile of ethics, law and professionalism in basic medical education. Investigación En Educación Médica, 3(12), 209-213. https://doi.org/10.1016/S2007-5057(14)70938-X 